\title{
Ki-67 is an independent prognostic marker for the recurrence and relapse of oral squamous cell carcinoma
}

\author{
YUE JING $^{1}$, QIAN ZHOU ${ }^{2}$, HUIDONG ZHU ${ }^{2}$, YE ZHANG ${ }^{2}$, YUXIAN SONG ${ }^{1}$, XIAOXIN ZHANG ${ }^{1}$, \\ XIAOFENG HUANG ${ }^{1}$, YAN YANG ${ }^{1}$, YANHONG NI ${ }^{1}$ and QINGANG HU ${ }^{2}$ \\ ${ }^{1}$ Central Laboratory; ${ }^{2}$ Department of Oral and Maxillofacial Surgery, Nanjing Stomatological Hospital, \\ Medical School of Nanjing University, Nanjing, Jiangsu 210008, P.R. China
}

Received February 1, 2018; Accepted August 15, 2018

DOI: $10.3892 / \mathrm{ol} .2018 .9647$

\begin{abstract}
As a nuclear and nucleolar protein, proliferation marker protein Ki-67 (Ki-67) serves a vital role in tumorigenesis due to its positive correlation with tumor proliferation. High expression of Ki-67 in the cell cycle from the $\mathrm{G}_{1}$ to $\mathrm{M}$ phase makes it a potential biomarker for certain tumors and useful for selecting medical treatment. However, the diagnostic value of Ki-67 in oral squamous cell carcinoma (OSCC) has not been fully evaluated. In the present study, the objective was the elucidation of the prognostic value of $\mathrm{Ki}-67$ in a large number of OSCC patients. Ki-67 expression was detected by immunohistochemical staining methods in 298 OSCC specimens and 98 tumor-free oral mucosa specimens (62 dysplasia mucosa and 36 normal mucosa), acquired from Nanjing Stomatological Hospital, Medical School of Nanjing University (Nanjing, China). Expression of Ki-67 in normal tissues, dysplasia tissues and OSCC tissues was compared. Associations between Ki-67 expression and clinicopathological parameters were analyzed by $\chi^{2}$ test. Kaplan-Meier survival curves and Cox progression analysis were used to assess the diagnostic value of $\mathrm{Ki}-67$ for OSCC. The results showed that Ki-67 expression was higher in OSCC tissues than in tumor-free tissues and that it increased with the progression of dysplasia in oral mucosa tissues. In addition, patients with high Ki-67 expression had a worse clinical outcome, including poor tumor differentiation $(\mathrm{P}=0.001)$, increased positive lymph node metastasis $(\mathrm{P}=0.006)$ and increased worst pattern of invasion type $(\mathrm{P}<0.0001)$. Kaplan-Meier survival analysis
\end{abstract}

Correspondence to: Dr Yanhong Ni, Central Laboratory, Nanjing Stomatological Hospital, Medical School of Nanjing University, 30 Zhongyang Road, Nanjing, Jiangsu 210008, P.R. China

E-mail: niyanhong12@163.com

Dr Qingang Hu, Department of Oral and Maxillofacial Surgery, Nanjing Stomatological Hospital, Medical School of Nanjing University, 30 Zhongyang Road, Nanjing, Jiangsu 210008, P.R. China E-mail: qghu@nju.edu.cn

Key words: proliferation marker protein $\mathrm{Ki}-67$, prognosis, oral squamous cell carcinoma demonstrated that higher Ki-67 expression was associated with poorer overall survival (OS) $(\mathrm{P}=0.035)$, recurrence-free survival (RFS) $(\mathrm{P}=0.017)$, metastasis-free survival (MFS) $(\mathrm{P}=0.032)$ and disease-free survival $(\mathrm{DFS})(\mathrm{P}=0.018)$ times. Additional multivariate analysis demonstrated that Ki-67 expression was negatively associated with OS, DFS, RFS and MFS. In conclusion, $\mathrm{Ki}-67$ overexpression is associated with the progression of OSCC and serves as an independent prognostic factor for OSCC patients.

\section{Introduction}

Oral squamous cell carcinoma (OSCC) is the most frequently found oral neoplasm by a considerable margin, accounting for $\sim 90 \%$ all types oral cancer (1). Due to a variety of factors, including a high degree of local invasiveness and metastasis to cervical lymph nodes (2), the survival rate of traditionally treated OSCC patients has improved slightly in the past three decades $(3,4)$. Regional or distant metastasis is one of the most crucial factors for the survival of patients. Therefore, searching for biomarkers associated with tumor progression has become a significant challenge in the diagnosis of $\operatorname{OSCC}(5,6)$.

Proliferation marker protein Ki-67 (Ki-67), a nuclear and nucleolar protein, is expressed in proliferating cells from the $\mathrm{G}_{1}$ to the $\mathrm{M}$ phase of the cell cycle, with the exception of the resting phase $\mathrm{G}_{0}(7)$. A sharp decrease in Ki-67 levels occurs in later phases of mitosis (8). Additionally, $\mathrm{Ki}-67$ has been shown to serve an important role in tumorigenesis due to its positive association with tumor proliferation and invasion (9), providing a marker of tumor aggressiveness.

Tumor cell proliferation is an important biological parameter for tumor diagnosis. High expression of Ki-67 in breast tumors shows higher proliferative and invasive activity (10). Kim et al found Ki-67 expression to be inversely associated with age and young age ${ }^{\text {/low }} \mathrm{Ki}-67$ patients (young age $<40$ years, low Ki67 level $<10 \%$ ) had significantly poorer recurrence-free survival (RFS) compared with older age ${ }^{\text {high }}$ patients (old age $\geq 40$ years, high Ki67 level $\geq 10 \%$ ) with breast cancer (10). Another study showed that high Ki-67 expression was associated with good clinical outcomes and could act as a good independent prognostic marker in colorectal cancer (11). It was also reported that $\mathrm{Ki}-67$, a proliferative marker, but not neuroendocrine expression, was an independent factor in 
predicting the prognosis of patients with prostate cancer (12). Furthermore, Ki-67 combined with other proteins can also be of diagnostic value. For example, certain studies found that a combination of B-cell lymphoma 2 protein and Ki-67 improved the detection of gastric cancer and identified metastatic castrate-resistant prostate cancer more accurately by assessing vimentin and Ki-67 expression $(13,14)$. Ki-67 was also reported to correlate with tumor progression in pancreatic neuroendocrine neoplasms (15).

Although Ki-67 has been reported to provide a diagnostic marker for neck metastasis in head and neck carcinomas (16), its role in OSCC has not been fully clarified. The present study aimed to evaluate the association between $\mathrm{Ki}-67$ expression and the clinicopathological features of OSCC patients to further assess its diagnostic value.

\section{Patients and methods}

Patients and tissue specimens. Paraffin-embedded surgical tissues were randomly collected from 298 OSCC patients, 62 patients with oral leukoplakia exhibiting various histological grades of oral epithelial dysplasia and a control group (36 patients) with normal oral tissues. The specimens were collected from resection surgery at Nanjing Stomatological Hospital, Medical School of Nanjing University (Nanjing, China) between March 2007 and December 2014. Diagnosis was confirmed by postoperative pathology, and no patients received radiotherapy or chemotherapy prior to surgery. Pregnant patients and those diagnosed with other diseases were excluded from the present study. The approval of the Ethics Committee of the Stomatological Hospital Affiliated Medical School, Nanjing University was obtained, as was informed consent from the patients or their families. All patients were followed up bimonthly until July 31, 2015.

Immunohistochemistry. Tissue specimens were fixed in $4 \%$ paraformaldehyde solution at $4^{\circ} \mathrm{C}$ for $24 \mathrm{~h}$, paraffin-embedded, and then cut into $2-\mu \mathrm{m}$ sections and placed on microscope slides for immunohistochemical analysis. In brief, the sections were successively incubated in xylene, $100 \%$ ethanol and $95 \%$ ethanol, blocked with $3 \% \mathrm{H}_{2} \mathrm{O}_{2}$ for $10 \mathrm{~min}$ at room temperature and washed. A rabbit monoclonal antibody for Ki-67 (cat. no. ab15580; 1:200 dilution; Abcam, Cambridge, MA, USA) was incubated with all slides at $4^{\circ} \mathrm{C}$ overnight followed by use of the secondary antibody from the Dako Real ${ }^{\mathrm{TM}}$ Envision $^{\mathrm{TM}}$ Detection System (cat. no. K500711; Dako; Agilent Technologies, Inc., Santa Clara, CA, USA), incubated at room temperature for $2 \mathrm{~h}$. DAB $(5 \mathrm{mg} / \mathrm{ml})$ chromogen detection (EnVision Detection System; Agilent Technologies, Inc., Sana Clara, CA, USA) for $10 \mathrm{~min}$ was followed by nuclear staining using $1 \mathrm{mg} / \mathrm{ml}$ of hematoxylin for $2 \mathrm{~min}$ at room temperature. Samples were washed with tap water for $10 \mathrm{~min}$, dehydrated, transparent, and detected with an inverted microscope (magnification, x200 and x400; Olympus CKX41; Olympus Corporation, Tokyo, Japan).

Quantification of immunohistochemistry. Analysis and evaluation of immunostaining results was independently determined by two pathologists. Differences of opinion were
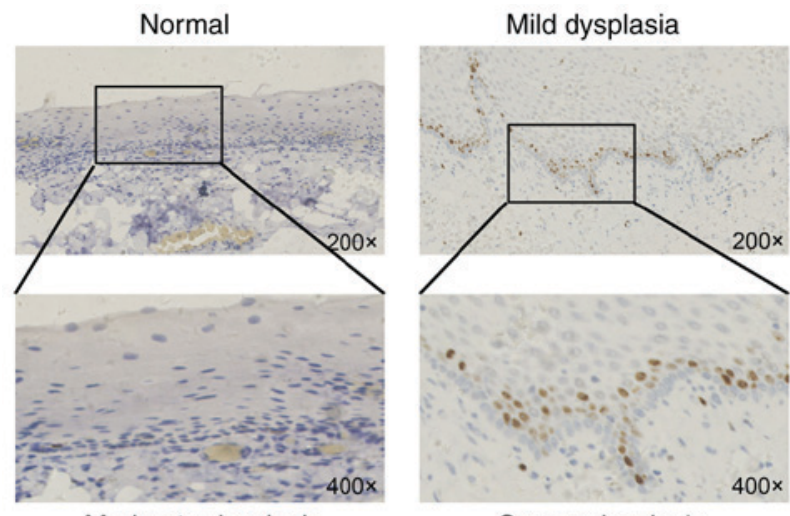

Moderate dysplasia
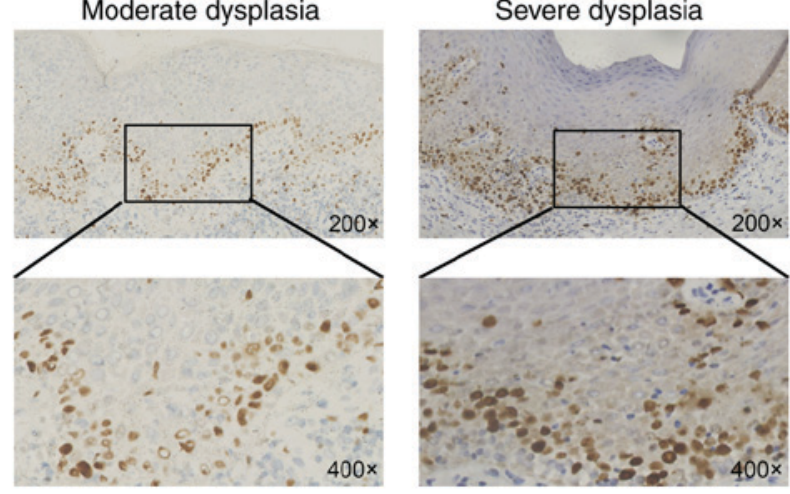

OSCC

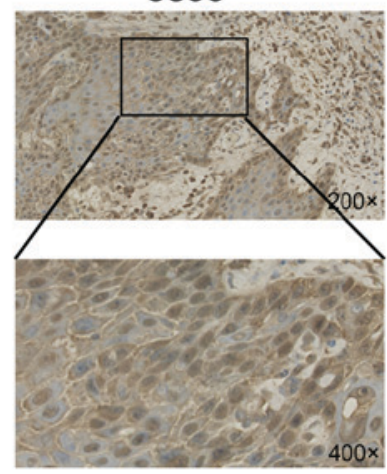

Figure 1. Immunohistochemical staining showing expression of Ki-67 in normal epithelial mucosa, oral mesenchyme and oral squamous cell carcinoma tissues. Ki-67 expression is mainly located in the basal cells and is more highly expressed than in normal mucosa. Additionally, Ki-67 is highly expressed in the tumor tissues and is mainly expressed in the nuclei of tumor cells. Ki-67, proliferation marker protein Ki-67.

reassessed together to reach consensus. Cells with brown staining under the microscope were considered as positive expression. The proportion of the number of Ki-67-positive cells to the number of total cells was recorded, and three different fields were examined within each micro-localization for the tumor specimen of each patient (9). The median proportion was used as a cutoff for further analysis of the Ki-67 high group (n=149) and the Ki-67 low group (n=149).

Statistical analysis. SPSS version 16.0 (SPSS Inc., Chicago, IL, USA) and the Prism statistical software package version 6.0 (GraphPad Software Inc., San Diego, CA, USA) were used for statistical analyses. The $\chi^{2}$ test was used to compare the Ki67 high group and the Ki67 low group. Overall survival (OS), disease-free survival (DFS), recurrence-free survival (RFS) and metastasis-free survival (MFS) were estimated comparing 
Table I. Ki-67 expression in normal mucosa, oral epithelial dysplasia and OSCC samples.

\begin{tabular}{|c|c|c|c|c|c|}
\hline \multirow[b]{2}{*}{ Sample type } & \multicolumn{2}{|c|}{ Ki-67 expression } & \multirow[b]{2}{*}{ High, n (\%) } & \multirow[b]{2}{*}{$\chi^{2}$} & \multirow[b]{2}{*}{ P-value } \\
\hline & $\mathrm{n}(\%)$ & Low, n (\%) & & & \\
\hline Normal oral mucosa & $36(9.0)$ & $20(10.1)$ & $16(8.0)$ & 2.828 & 0.568 \\
\hline Oral epithelial dysplasia & $62(15.7)$ & $29(14.6)$ & 33 (16.7) & & \\
\hline OSCC & $298(75.3)$ & $149(75.3)$ & $149(75.3)$ & & \\
\hline
\end{tabular}

Ki-67, proliferation marker protein Ki-67; OSCC, oral squamous cell carcinoma.

Table II. Associations between Ki-67 expression and various grades of oral epithelial dysplasia.

\begin{tabular}{lcccrr}
\hline & & \multicolumn{2}{c}{ Ki-67 expression } & & \\
\cline { 3 - 5 } Grade of oral epithelial dysplasia & $\mathrm{n}(\%)$ & Low, n (\%) & High, n (\%) & $\chi^{2}$ & P-value \\
\hline Mild & $9(14.5)$ & $3(33.3)$ & $6(66.7)$ & 7.685 & $0.029^{\mathrm{a}}$ \\
Moderate & $15(24.2)$ & $4(26.7)$ & $11(73.3)$ & & \\
Severe & $38(61.3)$ & $15(39.5)$ & $23(60.5)$ & & \\
\hline
\end{tabular}

${ }^{\mathrm{a}} \mathrm{P}<0.05 . \mathrm{Ki}-67$, proliferation marker protein $\mathrm{Ki}-67$.

high expression groups and low expression groups using Kaplan-Meier survival curves and the long-rank test. Survival time was defined as the interval between the date of surgery and the last date the patient was known to be disease-free or alive (censored). The Cox regression model was used to examine interactions between different prognostic factors in a multivariate analysis. Differences were considered statistically significant at $\mathrm{P}<0.05$.

\section{Results}

Ki-67 expression is associated with tumor progression. A total of 396 individuals (298 with OSCC, 62 with dysplasia and 36 with normal epithelia) were examined in the present study (Table I). Therefore, differences in Ki-67 expression by immunohistochemistry were analyzed from normal tissue to dysplasia and tumor tissues. It was found that $\mathrm{Ki}-67$ expression was rare in normal oral mucosa and that its expression was mainly located in the basal cells, where it exhibited higher expression than that in normal mucosa (Fig. 1). Ki-67 was highly expressed in the tumor tissues and was mainly expressed in the nuclei of tumor cells. The immunohistochemistry indicated that the Ki-67 high group with oral dysplasia of the epithelial mucosa accounted for $16.7 \%(n=33)$ of the total number of high Ki-67 expression cases, while the Ki-67 low group with oral dysplasia of the epithelial mucosa accounted for $14.6 \%(n=29)$ of the total number of cases with low Ki-67 expression (Table I).

As the dysplasia of oral epithelial mucosa included mild, moderate and severe dysplasia, Ki-67 expression was analyzed in these three types of tissues. The results showed that Ki-67 expression increased from mild dysplasia to moderate to severe, and demonstrated that the expression of $\mathrm{Ki}-67$ increased with the decreased severity of oral leukoplakia: Mild dysplasia $(n=9), 14.5 \%$; moderate dysplasia $(n=15), 24.2 \%$; and severe dysplasia $(\mathrm{n}=38), 61.3 \%(\mathrm{P}=0.029$; Table II).

Associations between $\mathrm{Ki}-67$ expression and clinicopathological characteristics. The associations were investigated between Ki-67 expression and clinicopathological characteristics, including sex, age, smoking habits, Tumor-Node-Metastasis (TNM) stage (17), tumor differentiation, lymph node metastasis status, depth of tumor invasion (DOI) and worst pattern of invasion (WPOI) type (18). The results demonstrated that $\mathrm{Ki}-67$ expression was significantly associated with patient age $(\mathrm{P}=0.011$; Table III), demonstrating that younger people ( $<60$ years) exhibited lower Ki-67 expression. Additionally, Ki-67 was highly expressed in patients with moderate-high differentiation $(\mathrm{P}=0.001$; Table III) and patients with lymph node metastasis $(\mathrm{P}=0.006$; Table III). In addition, $\mathrm{Ki}-67$ expression was found to be higher in patients with WPOI types 4-5 than in those with types $1-3(\mathrm{P}<0.0001$; Table III), but there was no significant difference between the DOI $<5$ and $\geq 5$ mm groups ( $\mathrm{P}=0.082$; Table III).

Associations between Ki-67 expression and survival time. Follow-up data was obtained and the association between Ki-67 expression and the clinical outcome of the patients was analyzed. All patients were separated into two groups according to $\mathrm{Ki}-67$ expression using the median as the cutoff value. The association between OS, DFS, RFS, metastasis-free survival (MFS) and Ki-67 expression was then analyzed with Kaplan-Meier survival curves. The results demonstrated that higher Ki-67 expression was associated with poorer OS ( $\mathrm{P}=0.035$; Fig. 2A), RFS ( $\mathrm{P}=0.017$; Fig. 2B), MFS ( $\mathrm{P}=0.032$; Fig. 2C) and DFS ( $\mathrm{P}=0.018$; Fig. 2D) times. These results suggested that higher Ki-67 expression in OSCC patients was associated with an unsatisfactory clinical outcome. 
Table III. Ki-67 expression ratio and clinicopathological characteristics in patients with oral squamous cell carcinoma.

\begin{tabular}{|c|c|c|c|c|c|c|}
\hline \multirow[b]{2}{*}{ Variable } & \multirow[b]{2}{*}{ Category } & \multirow[b]{2}{*}{$\mathrm{n}(\%)$} & \multicolumn{2}{|c|}{ Ki-67 expression } & \multirow[b]{2}{*}{$\chi^{2}$} & \multirow[b]{2}{*}{ P-value } \\
\hline & & & Low, n (\%) & High, n (\%) & & \\
\hline Sex & $\begin{array}{l}\text { Male } \\
\text { Female }\end{array}$ & $\begin{array}{l}152(51) \\
146(49)\end{array}$ & $\begin{array}{l}72(48.3) \\
77(51.7)\end{array}$ & $\begin{array}{l}80(53.7) \\
69(46.3)\end{array}$ & 0.859 & 0.354 \\
\hline Age & $\begin{array}{l}<60 \text { years } \\
\geq 60 \text { years }\end{array}$ & $\begin{array}{l}138(46.3) \\
160(53.7)\end{array}$ & $\begin{array}{l}80(53.7) \\
69(46.3)\end{array}$ & $\begin{array}{l}58(38.9) \\
91(61.1)\end{array}$ & 6.532 & $0.011^{\mathrm{a}}$ \\
\hline TNM & $\begin{array}{l}\text { I-III } \\
\text { IV-V }\end{array}$ & $\begin{array}{c}295(99) \\
3(1)\end{array}$ & $\begin{array}{c}148(99.3) \\
1(0.7)\end{array}$ & $\begin{array}{c}147(98.7) \\
2(1.3)\end{array}$ & 0.337 & 0.562 \\
\hline Differentiation & $\begin{array}{l}\text { Low } \\
\text { Moderate-high }\end{array}$ & $\begin{array}{l}149(50) \\
149(50)\end{array}$ & $\begin{array}{l}89(59.7) \\
60(40.3)\end{array}$ & $\begin{array}{l}60(40.3) \\
89(59.7)\end{array}$ & 11.289 & $0.001^{\mathrm{a}}$ \\
\hline Lymph node metastasis & $\begin{array}{l}\text { Yes } \\
\text { No }\end{array}$ & $\begin{array}{c}11(3.7) \\
287(96.3)\end{array}$ & $\begin{array}{c}1(0.7) \\
148(99.3)\end{array}$ & $\begin{array}{c}10(6.7) \\
139(93.3)\end{array}$ & 7.646 & $0.006^{\mathrm{a}}$ \\
\hline Depth of invasion & $\begin{array}{l}<5 \mathrm{~mm} \\
\geq 5 \mathrm{~mm}\end{array}$ & $\begin{array}{l}143(48) \\
155(52)\end{array}$ & $\begin{array}{l}79(53) \\
70(47)\end{array}$ & $\begin{array}{l}64(43) \\
85(57)\end{array}$ & 3.025 & 0.082 \\
\hline WPOI & $\begin{array}{l}\text { I-III } \\
\text { IV-V }\end{array}$ & $\begin{array}{l}174(58.4) \\
124(41.6)\end{array}$ & $\begin{array}{r}103(69.1) \\
46(30.9)\end{array}$ & $\begin{array}{l}71(47.7) \\
78(52.3)\end{array}$ & 14.143 & $<0.0001^{\mathrm{a}}$ \\
\hline
\end{tabular}

${ }^{\text {ap }<0.05 . ~ K i-67, ~ p r o l i f e r a t i o n ~ m a r k e r ~ p r o t e i n ~ K i-67 ; ~ T N M, ~ T u m o r-N o d e-M e t a s t a s i s ; ~ W P O I, ~ w o r s t ~ p a t t e r n ~ o f ~ i n v a s i o n . ~}$

Table IV. Prognostic factors in the Cox proportional hazards model for overall survival.

\begin{tabular}{|c|c|c|c|c|c|c|c|}
\hline \multirow[b]{2}{*}{ Variable } & \multirow[b]{2}{*}{ Category } & \multicolumn{3}{|c|}{ Univariate } & \multicolumn{3}{|c|}{ Multivariate } \\
\hline & & HR & $95 \%$ CI & P-value & HR & $95 \% \mathrm{CI}$ & P-value \\
\hline Sex & Male vs. female & 1.138 & $0.899-1.442$ & 0.281 & 1.114 & $0.877-1.414$ & 0.378 \\
\hline Age & $<60$ vs. $\geq 60$ years & 1.208 & $0.953-1.53$ & 0.118 & 1.154 & $0.906-1.469$ & 0.246 \\
\hline TNM & I-III vs. IV-V & 0.081 & $0.025-0.262$ & $<0.0001^{\mathrm{a}}$ & 0.08 & $0.024-0.264$ & $<0.0001^{\mathrm{a}}$ \\
\hline Differentiation & Low vs. moderate-high & 0.662 & $0.521-0.842$ & $0.001^{\mathrm{a}}$ & 0.659 & $0.507-0.858$ & $0.002^{\mathrm{a}}$ \\
\hline Lymph node metastasis & Yes vs. no & 1.003 & $0.372-2.704$ & 0.996 & 1.159 & $0.425-3.162$ & 0.773 \\
\hline Depth of invasion & $<5 \mathrm{vs} . \geq 5 \mathrm{~mm}$ & 1.011 & $0.798-1.28$ & 0.929 & 1.137 & $0.879-1.47$ & 0.329 \\
\hline WPOI & I-III vs. IV-V & 0.912 & $0.715-1.164$ & 0.461 & 1.015 & $0.776-1.326$ & 0.915 \\
\hline Ki-67 & Low vs. high expression & 1.893 & $1.136-3.573$ & $0.035^{\mathrm{a}}$ & 1.261 & $1.051-3.287$ & $0.044^{\mathrm{a}}$ \\
\hline
\end{tabular}

${ }^{a} \mathrm{P}<0.05$. HR, hazard ratio; CI, confidence interval; TNM, Tumor-Node-Metastasis; WPOI, worst pattern of invasion; Ki-67, proliferation marker protein Ki-67.

Ki-67 expression is an independent diagnostic marker for OSCC. Univariate analysis revealed that the following parameters were associated with increased mortality: TNM [OS: Hazard ratio (HR), 0.081; 95\% confidence interval (CI), 0.025-0.262; P<0.0001; DFS: HR, 0.107; 95\% CI, 0.033-0.345; P<0.0001; RFS: HR, 0.106; 95\% CI, 0.033-0.341; $\mathrm{P}<0.0001 ; \mathrm{MFS}: \mathrm{HR}, 0.083 ; 95 \% \mathrm{CI}$, 0.025-0.267; $\mathrm{P}<0.0001]$, differentiation (OS: HR, 0.662; 95\% CI, 0.521-0.842; P=0.001; DFS: HR, 0.724; 95\% CI, 0.57-0.919; $\mathrm{P}=0.008$; RFS: HR, 0.735; 95\% CI, 0.579-0.933; $\mathrm{P}=0.011$; MFS: HR, 0.652; 95\% CI, 0.513-0.829; $\mathrm{P}<0.0001)$ and Ki-67 expression (OS: HR, 1.893; 95\% CI, 1.136-3.573; $\mathrm{P}=0.035$; DFS: HR, 2.283; 95\% CI, 1.408-3.766; $\mathrm{P}=0.018$; RFS: HR, 2.43; 95\% CI, 1.437-3.428; $\mathrm{P}=0.017$; MFS:
HR, 2.048; 95\% CI, 1.165-3.393; $\mathrm{P}=0.032$ ). In a further step of multivariate analysis, $\mathrm{Ki}-67$ expression retained its negative impact on survival for OS, DFS, RFS and MFS (Tables IV-VII).

\section{Discussion}

OSCC is among the most frequently diagnosed cancer types worldwide. However, despite improved therapies, the 5-year survival rate has not changed. Overall, $>50 \%$ of patients with OSCC demonstrate regional and distant metastases, which result in treatment failures and occasionally mortality within a year due to recurrent or metastatic disease $(19,20)$. In order to improve the survival rate for OSCC, identification of an 
Table V. Prognostic factors in the Cox proportional hazards model for disease-free survival.

\begin{tabular}{|c|c|c|c|c|c|c|c|}
\hline \multirow[b]{2}{*}{ Variable } & \multirow[b]{2}{*}{ Category } & \multicolumn{3}{|c|}{ Univariate } & \multicolumn{3}{|c|}{ Multivariate } \\
\hline & & HR & $95 \% \mathrm{CI}$ & P-value & HR & $95 \% \mathrm{CI}$ & P-value \\
\hline Sex & Male vs. female & 1.15 & $0.916-1.467$ & 0.220 & 1.136 & $0.896-1.442$ & 0.292 \\
\hline Age & $<60$ vs. $\geq 60$ years & 1.135 & $0.896-1.438$ & 0.293 & 1.103 & $0.867-1.403$ & 0.426 \\
\hline TNM & I-III vs. IV-V & 0.107 & $0.033-0.345$ & $<0.0001^{\mathrm{a}}$ & 0.1 & $0.031-0.327$ & $<0.0001^{\mathrm{a}}$ \\
\hline Differentiation & Low vs. moderate-high & 0.724 & $0.57-0.919$ & $0.008^{\mathrm{a}}$ & 0.737 & $0.568-0.957$ & $0.022^{\mathrm{a}}$ \\
\hline Lymph node metastasis & Yes vs. no & 0.572 & $0.209-1.561$ & 0.276 & 0.592 & $0.215-1.631$ & 0.311 \\
\hline Depth of invasion & $<5 \mathrm{vs} . \geq 5 \mathrm{~mm}$ & 1.009 & $0.797-1.277$ & 0.943 & 1.123 & $0.872-1.448$ & 0.369 \\
\hline WPOI & I-III vs. IV-V & 0.88 & $0.69-1.121$ & 0.301 & 0.961 & $0.738-1.252$ & 0.769 \\
\hline Ki-67 & Low vs. high expression & 2.283 & $1.408-3.766$ & $0.018^{\mathrm{a}}$ & 1.828 & $1.056-3.149$ & $0.043^{\mathrm{a}}$ \\
\hline
\end{tabular}

${ }^{a} \mathrm{P}<0.05$. HR, hazard ratio; CI, confidence interval; TNM, Tumor-Node-Metastasis; WPOI, worst pattern of invasion; Ki-67, proliferation marker protein Ki-67.

Table VI. Prognostic factors in the Cox proportional hazards model for recurrence-free survival.

\begin{tabular}{|c|c|c|c|c|c|c|c|}
\hline \multirow[b]{2}{*}{ Variable } & \multirow[b]{2}{*}{ Category } & \multicolumn{3}{|c|}{ Univariate } & \multicolumn{3}{|c|}{ Multivariate } \\
\hline & & HR & $95 \% \mathrm{CI}$ & P-value & HR & $95 \% \mathrm{CI}$ & P-value \\
\hline Sex & Male vs. female & 1.143 & $0.903-1.448$ & 0.265 & 1.127 & $0.888-1.431$ & 0.327 \\
\hline Age & $<60$ vs. $\geq 60$ years & 1.122 & $0.886-1.422$ & 0.340 & 1.083 & $0.851-1.378$ & 0.516 \\
\hline TNM & I-III vs. IV-V & 0.106 & $0.033-0.341$ & $<0.0001^{\mathrm{a}}$ & 0.102 & $0.031-0.333$ & $<0.0001^{\mathrm{a}}$ \\
\hline Differentiation & Low vs. moderate-high & 0.735 & $0.579-0.933$ & $0.011^{\mathrm{a}}$ & 0.736 & $0.567-0.956$ & $0.022^{\mathrm{a}}$ \\
\hline Lymph node metastasis & Yes vs. no & 1.088 & $0.404-2.932$ & 0.868 & 1.227 & $0.45-3.345$ & 0.690 \\
\hline Depth of invasion & $<5$ vs. $\geq 5 \mathrm{~mm}$ & 1.023 & $0.808-1.296$ & 0.848 & 1.139 & $0.884-1.47$ & 0.314 \\
\hline WPOI & I-III vs. IV-V & 0.897 & $0.703-1.143$ & 0.378 & 0.962 & $0.738-1.254$ & 0.774 \\
\hline Ki-67 & Low vs. high expression & 2.43 & $1.437-3.428$ & $0.017^{\mathrm{a}}$ & 2.461 & $1.308-4.571$ & $0.024^{\mathrm{a}}$ \\
\hline
\end{tabular}

${ }^{a} \mathrm{P}<0.05$. HR, hazard ratio; CI, confidence interval; TNM, Tumor-Node-Metastasis; WPOI, worst pattern of invasion; Ki-67, proliferation marker protein Ki-67.
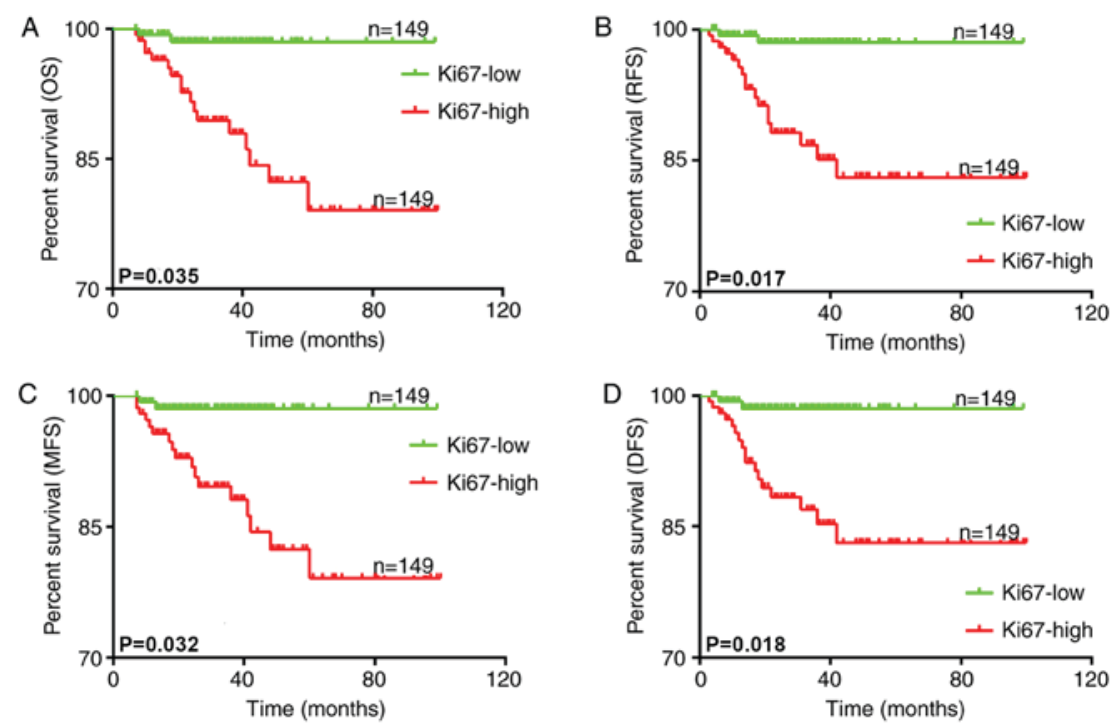

Figure 2. Kaplan-Meier survival curves for (A) OS, (B) RFS, (C) MFS and (D) DFS times of patients with oral squamous cell carcinoma according to the expression ratio of $\mathrm{Ki}-67$. The analysis of the survival times and $\mathrm{Ki}-67$ expression demonstrated that higher Ki-67 expression was associated with poorer OS, RFS, MFS and DFS times. OS, overall survival; RFS, recurrence-free survival; MFS, metastasis-free survival; DFS, disease-free survival; Ki-67, proliferation marker protein Ki-67. 
Table VII. Prognostic factors in the Cox proportional hazards model for metastasis-free survival.

\begin{tabular}{|c|c|c|c|c|c|c|c|}
\hline \multirow[b]{2}{*}{ Variable } & \multirow[b]{2}{*}{ Category } & \multicolumn{3}{|c|}{ Univariate } & \multicolumn{3}{|c|}{ Multivariate } \\
\hline & & HR & $95 \% \mathrm{CI}$ & P-value & HR & $95 \% \mathrm{CI}$ & P-value \\
\hline Sex & Male vs. female & 1.152 & $0.91-1.459$ & 0.239 & 1.123 & $0.885-1.425$ & 0.340 \\
\hline Age & $<60$ vs. $\geq 60$ years & 1.223 & $0.965-1.549$ & 0.096 & 1.178 & $0.925-1.5$ & 0.185 \\
\hline TNM & I-III vs. IV-V & 0.083 & $0.025-0.267$ & $<0.0001^{\mathrm{a}}$ & 0.078 & $0.024-0.258$ & $<0.0001^{\mathrm{a}}$ \\
\hline Differentiation & Low vs. moderate-high & 0.652 & $0.513-0.829$ & $<0.0001^{\mathrm{a}}$ & 0.66 & $0.508-0.858$ & $0.002^{\mathrm{a}}$ \\
\hline Lymph node metastasis & Yes vs. no & 0.498 & $0.182-1.363$ & 0.175 & 0.506 & $0.183-1.398$ & 0.189 \\
\hline Depth of invasion & $<5 \mathrm{vs} . \geq 5 \mathrm{~mm}$ & 0.997 & $0.787-1.263$ & 0.979 & 1.119 & $0.866-1.446$ & 0.390 \\
\hline WPOI & I-III vs. IV-V & 0.896 & $0.703-1.143$ & 0.377 & 1.015 & $0.777-1.325$ & 0.916 \\
\hline Ki-67 & Low vs. high expression & 2.048 & $1.165-3.393$ & $0.032^{\mathrm{a}}$ & 3.301 & $1.077-10.116$ & $0.037^{\mathrm{a}}$ \\
\hline
\end{tabular}

${ }^{\mathrm{a}} \mathrm{P}<0.05$. HR, hazard ratio; CI, confidence interval; TNM, Tumor-Node-Metastasis; WPOI, worst pattern of invasion; Ki-67, proliferation marker protein Ki-67.

underlying molecular event differentiating patients at risk for progression at the premalignant stage, is required (21). Factors, including tumor size, lymph node metastasis, TNM type and differentiation, influence the prognosis of OSCC (22).

$\mathrm{Ki}-67$ is an indicator of cell proliferation and has been shown to be upregulated in numerous tumors $(23,24)$. Tumor proliferative activity labeled by $\mathrm{Ki}-67$ has been found to be associated with tumor aggression, which is specified by tumor grade and stage. Several studies have described these associations and identified $\mathrm{Ki}-67$ as a prognostic factor $(14,25-27)$. The present study found upregulation of $\mathrm{Ki}-67$ expression with tumor progression using normal epithelial mucosa, dysplasia and OSCC samples. In addition, $\mathrm{Ki}-67$ expression also increased from mild to moderate to severe dysplasia. Another important finding was that high expression of $\mathrm{Ki}-67$ was associated with severe differentiation $(\mathrm{P}=0.001)$, lymph node metastasis $(\mathrm{P}=0.006)$ and higher WPOI $(\mathrm{P}<0.0001)$. Furthermore, high Ki-67 expression was significantly associated with poor survival time with regards to $\mathrm{OS}(\mathrm{P}=0.035), \operatorname{RFS}(\mathrm{P}=0.017)$, MFS $(\mathrm{P}=0.032)$ and DFS $(\mathrm{P}=0.018)$. The biological behavior of OSCC with highly expressed $\mathrm{Ki}-67$ is verified by the association between $\mathrm{Ki}-67$ and affiliated potential clinicopathological characteristics; for example, differentiation, lymph node metastasis, TNM, DOI and WPOI. Unexpectedly, the multivariate analysis revealed that $\mathrm{Ki}-67$ could be an independent predictor for OS, RFS, MFS and RFS.

In summary, the findings of the present study strongly argue for the value of highly expressed $\mathrm{Ki}-67$ as an independent prognostic marker for OSCC. Considering the extensive heterogeneity of tumors, further researches need to enrich correlations of spatial expression of Ki67 with OSCC.

\section{Acknowledgements}

The authors would like to thank Dr K. D. Tanq (School of Biomedical Sciences, Institute of Health and Biomedical Innovation, Queensland University of Technology, Brisbane, Queensland, Australia) for assisting in the drafting of the original manuscript.

\section{Funding}

The present study was supported by the National Natural Science Foundation of China (grant nos. 81772880 and 81702680), the Nanjing Medical Science and Technique Development Foundation (grant nos. YKK16164 and QRX17083), the Jiangsu Provincial Key Medical Discipline (since 2017), Nanjing Municipal Key Medical Laboratory Constructional Project Funding (since 2016), and the Center of Nanjing Clinical Medicine of Tumor project (since 2014).

\section{Availability of data and materials}

The datasets used and/or analyzed during the current study are available from the corresponding author on reasonable request.

\section{Authors' contributions}

YJ performed the histological examination of the OSCC samples, analyzed the data and wrote the manuscript. QZ, $\mathrm{HZ}$ and YZ analyzed the OSCC patient data. YS and XZ participated in the statistical analyses. XH contributed to the interpretation of the OSCC patient data. YY participated in the histological examination of OSCC. YN designed the study and drafted the manuscript. QH conceived and designed the study. All authors read and approved the submitted manuscript.

\section{Ethics approval and consent to participate}

The study was approved by the Ethics Committee of the Stomatological Hospital Affiliated Medical School, Nanjing University. Written informed consent was obtained from the patients.

\section{Patient consent for publication}

Written informed consent was obtained from the patients for the publication of any associated data and accompanying images. 


\section{Competing interests}

The authors declare that they have no competing interests.

\section{References}

1. Bagan J, Sarrion G and Jimenez Y: Oral cancer: Cral precancer and cancer and preventive measures. Clinical Oral investigations 5 207-213, 2001.

2. Reichart PA: Identification of risk groups for oral precancer and cancer and preventive measures. Clin Oral Investig 5: 207-213, 2001

3. Perez-Sayans M, Somoza-Martin JM, Barros-Angueira F, Reboiras-Lopez MD, Gandara Rey JM and Garcia-Garcia A: Genetic and molecular alterations associated with oral squamous cell cancer (Review). Oncol Rep 22: 1277-1282, 2009.

4. Sasahira T, Kirita T and Kuniyasu H: Update of molecular pathobiology in oral cancer: A review. Int J Clin Oncol 19: 431-436, 2014.

5. Ost P, Bossi A, Decaestecker K, De Meerleer G, Giannarini G Karnes RJ, Roach M III and Briganti A: Metastasis-directed therapy of regional and distant recurrences after curative treatment of prostate cancer: A systematic review of the literature. Eur Urol 67: 852-863, 2015

6. Sannam Khan R, Khurshid Z, Akhbar S and Faraz Moin S: Advances of Salivary Proteomics in Oral Squamous Cell Carcinoma (OSCC) Detection: An Update. Proteomes 4: piii: $\mathrm{E} 41,2016$.

7. Gerdes J, Lemke H, Baisch H, Wacker HH, Schwab U and Stein H: Cell cycle analysis of a cell proliferation-associated human nuclear antigen defined by the monoclonal antibody Ki-67. J Immunol 133: 1710-1715, 1984.

8. Li LT, Jiang G, Chen Q and Zheng JN: Ki67 is a promising molecular target in the diagnosis of cancer (review). Mol Med Rep 11: 1566-1572, 2015.

9. Antonarakis ES, Keizman D, Zhang Z, Gurel B, Lotan TL, Hicks JL, Fedor HL, Carducci MA, De Marzo AM and Eisenberger MA: An immunohistochemical signature comprising PTEN, MYC, and Ki67 predicts progression in prostate cancer patients receiving adjuvant docetaxel after prostatectomy. Cancer 118: 6063-6071, 2012.

10. Kim J, Han W, Jung SY, Park YH, Moon HG, Ahn SK, Lee JW, Kim MK, Kim JJ, Lee ES, et al: The Value of Ki67 in Very Young Women with hormone receptor-positive breast cancer: Retrospective Analysis of 9,321 Korean Women. Ann Surg Oncol 22: 3481-3488, 2015.

11. Melling N, Kowitz CM, Simon R, Bokemeyer C, Terracciano L, Sauter G, Izbicki JR and Marx AH: High Ki67 expression is an independent good prognostic marker in colorectal cancer. J Clin Pathol 69: 209-214, 2016.

12. Pascale M, Aversa C, Barbazza R, Marongiu B, Siracusano S, Stoffel F, Sulfaro S, Roggero E, Bonin S and Stanta G: The proliferation marker Ki67, but not neuroendocrine expression, is an independent factor in the prediction of prognosis of primary prostate cancer patients. Radiol Oncol 50: 313-320, 2016.

13. Zhou Y, Li Y, Zheng J, Liu K and Zhang H: Detecting of gastric cancer by Bcl-2 and Ki67. Int J Clin Exp Pathol 8: 7287-7290, 2015.

14. Lindsay CR, Le Moulec S, Billiot F, Loriot Y, Ngo-Camus M, Vielh P, Fizazi K, Massard C and Farace F: Vimentin and Ki67 expression in circulating tumour cells derived from castrate-resistant prostate cancer. BMC Cancer 16: 168, 2016.
15. Panzuto F, Cicchese N, Partelli S, Rinzivillo M, Capurso G, Merola E, Manzoni M, Pucci E, Iannicelli E, Pilozzi E, et al: Impact of Ki67 re-assessment at time of disease progression in patients with pancreatic neuroendocrine neoplasms. PLoS One 12: e0179445, 2017

16. Liu M, Lawson G, Delos M, Jamart J, Ide C, Coche E, Weynand B, Desuter G, Hamoir M, Remacle M and Marbaix E: Predictive value of the fraction of cancer cells immunolabeled for proliferating cell nuclear antigen or Ki67 in biopsies of head and neck carcinomas to identify lymph node metastasis: Comparison with clinical and radiologic examinations. Head Neck 25: 280-288, 2003.

17. Keohane SG, Proby CM, Newlands C, Motley RJ, Nasr I, Mohd Mustapa MF and Slater DN: The new 8th edition of TNM staging and its implications for skin cancer: a review by the British Association of Dermatologists and the Royal College of Pathologists, United Kingdom. Br J Dermatol, 2018 (Epub ahead of print).

18. Heerema MG, Melchers LJ, Roodenburg JL, Schuuring E, de Bock GH and van der Vegt B: Reproducibility and prognostic value of pattern of invasion scoring in low-stage oral squamous cell carcinoma. Histopathology 68: 388-397, 2016.

19. Kuperman DI, Auethavekiat V, Adkins DR, Nussenbaum B, Collins S, Boonchalermvichian C, Trinkaus K, Chen L and Morgensztern D: Squamous cell cancer of the head and neck with distant metastasis at presentation. Head Neck 33: 714-718, 2011.

20. Chen W, Zheng R, Baade PD, Zhang S, Zeng H, Bray F, Jemal A, $\mathrm{Yu}$ XQ and He J: Cancer statistics in China, 2015. CA Cancer J Clin 66: 115-132, 2016.

21. Towle R, Truong D and Garnis C: Epigenetic mediated silencing of EYA4 contributes to tumorigenesis in oral dysplastic cells. Genes Chromosomes Cancer 55: 568-576, 2016.

22. Noguti J, De Moura CF, De Jesus GP, Da Silva VH, Hossaka TA, Oshima CT and Ribeiro DA: Metastasis from oral cancer: An overview. Cancer Genomics Proteomics 9: 329-335, 2012.

23. Yurakh AO, Ramos D, Calabuig-Farinas S, López-Guerrero JA, Rubio J, Solsona E, Romanenko AM, Vozianov AF, Pellin A and Llombart-Bosch A: Molecular and immunohistochemical analysis of the prognostic value of cell-cycle regulators in urothelial neoplasms of the bladder. Eur Urol 50: 506-515, 2006.

24. Brown DC, Gatter KC: Ki67 protein: The immaculate deception? Histopathology 40: 2-11, 2002.

25. Wu TT, Chen JH, Lee YH and Huang JK: The role of bcl-2, p53, and ki-67 index in predicting tumor recurrence for low grade superficial transitional cell bladder carcinoma. J Urol 163: 758-760, 2000

26. Li H, Han X, Liu Y, Liu G and Dong G: Ki67 as a predictor of poor prognosis in patients with triple-negative breast cancer. Oncol Lett 9: 149-152, 2015.

27. Li W, Zhang G, Wang HL and Wang L: Analysis of expression of cyclin E, p27kip1 and Ki67 protein in colorectal cancer tissues and its value for diagnosis, treatment and prognosis of disease. Eur Rev Med Pharmacol Sci 20: 4874-4879, 2016.

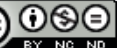

This work is licensed under a Creative Commons Attribution-NonCommercial-NoDerivatives 4.0 International (CC BY-NC-ND 4.0) License. 